\title{
AHCY wt Allele
}

National Cancer Institute

\section{Source}

National Cancer Institute. AHCY wt Allele. NCI Thesaurus. Code C104864.

Human AHCY wild-type allele is located in the vicinity of $20 q 11.22$ and is approximately 32 $\mathrm{kb}$ in length. This allele, which encodes adenosylhomocysteinase protein, is involved in the metabolism of amino acids. Mutation of the gene is associated with hypermethioninemia with S-adenosylhomocysteine hydrolase deficiency. 